\title{
Systematic Design Method for Co-creation of 3D Printing Service
}

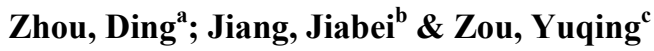 \\ ${ }^{a}$ School of Industrial Design, Nanjing University of the Arts, China, zhoudingshanshan@gmail.com, \\ ${ }^{\mathrm{b}}$ School of Industrial Design, Nanjing University of the Arts, China, 370131388@qq.com, \\ ${ }^{c}$ School of Industrial Design, Nanjing University of the Arts, China, 106130619@qq.com,
}

\begin{abstract}
Background: As one of the objectives of Design for Additive Manufacture, the customized geometry promotes $3 D$ printing to increasingly realize product customization in the service market. Defined as a business strategy which focuses on customer experience and interaction, co-creation is expected to obtain a fast-growing market volume. Recently, some co-creation of $3 D$ printing service (3DPS) has been released to realize value creation. Despite of its rapid growth, there are rare researches on this field, especially those about its design method.
\end{abstract}

Aim: To define a systematic design method for developing the co-creation of 3DPS.

Method: Firstly, this research distinguished ambiguous type and definite type of 3DPS cocreation. The latter was taken as the current research object, because it presents the services scope more clearly. Furthermore, in order to solve the problem about the research, that is, what the essential components constructing the 3DPS co-creation are, evidence needed to be collected based on observation of the mentioned cases. Therefore, holistic multiple-case study of 3DPS co-creation samples was designed and conducted, as it was herein applied as the research method. This research is divided into three sections. The first section presents the preparation for data collection, including case selection and the formulation of evidence collection. The second section analyzes the collected evidences. Based on the evidence analysis, the third section concludes the knowledge of 3DPS cocreation.

In order to collect adequate evidences, a pair of models was applied to build a framework. The first one is the Den Hertog's service innovation model which presents four dimensions including new service concept, new client interface, new service delivery system, and technological options. The other model refers to the building blocks of interactions for value co-creation: dialogue, access, risk-benefits, and transparency. It presents the components in basis construction, which are necessary for the interactions between a consumer and a service provider.

Finding: the system of 3DPS co-creation is composed by three dialogues including related accesses and interfaces, and the to-be-3D printed outcome. The three accesses provide customers with the entrances of knowing service concept, co-creating geometry, and accepting service delivery. The interfaces bring corresponding dialogues between accesses 
and customer to reach each process goal. The outcome of co-creation refers to the $3 D$ printed artifact or $3 D$ digital model.

Conclusion: This research proposes a four-step systemic design method for co-creation of 3DPS. Firstly, the dialogue with the interface of service concept introduction and the access to know it is constructed. Secondly, the dialogue based on the interface of cocreation with design variables, and the access of co-creating geometry is built. WebGL supports its $3 D$ graphics. Thirdly, the interface of purchasing or downloading, and the access of accepting service delivery compose the dialogue of this step. Fourthly, the customized artifact shall be treated by $3 D$ printing and then delivered to customers; or a $3 D$ digital model gets ready for downloading.

Keywords: co-creation, $3 D$ printing service, product customization, service innovation, design method

\section{Introduction}

Co-creation is defined as an active, creative and social collaborative process between producers and users and aims to create values for customers (Piller et al., 2010). Nowadays, consumers join idea generation for new products, co-create products with firms, test finished products and provide end users with product support (Nambisan, 2002). As a business strategy which focuses on customer experience and interactive relationships, co-creation is expected to obtain a fast-growing market volume (Dervojeda et al., 2014; Sanders \& Stappers, 2008).

What is the most powerful tool to realize co-creation? As one of the objectives of Design for Additive Manufacture, customized geometry can promote application of 3D printing technology to gradually realize product customization in the service market (Gibson, Rosen \& Stucker, 2010). Meanwhile, in comparison with scanning-based customization, co-creation provides a flexible format in which the 3D printing technology is applied more efficiently and extensively. Until now, various kinds of co-creation of $3 \mathrm{D}$ printing service (hereafter referred to as 3DPS) were released on the Internet to realize value creation. Through the web-based 3D visualized interface, a customer can create and customize his or her own product, and can then obtain the tangible outcome which will be treated by 3D printing of the service supplier.

Despite of the rapid growth of 3DPS co-creation, there were rare researches on this field, especially those about its design method. In 2015, Rayna, Striukova, and Darlington investigated the changes brought by online 3D printing platforms in co-creation and user innovation. The authors concluded that co-creation initiates transformation from consumers to prosumers, and 3D printing technology helps co-creation to exert its full potential. Rayna et al. (2015) also suggested: "for this to happen, adequate co-creation platforms shall be built and this requires full understanding the different aspects of co-creation, the consequences of pro-consumption and the key roles of information systems." (p.101). Nevertheless, the prior research may not be highly beneficial for 3DPS providers to build a co-creation format effectively. 
Through investigation of specific essential components of 3DPS co-creation, this research aims to define a systematic design method for developing the co-creation of 3DPS. Based on a pair of theoretical bases, holistic multiple-case study was carried out here aiming at a group of 3DPS co-creation samples. The cases refer to the definite-type 3DPS co-creation which presents the clear scope of services.

The article is divided into three sections. The first section presents the preparation for data collection, including case selection and formulation of evidence collection. The second section analyzes the collected evidences. Based on the evidence analysis, the third section concludes the knowledge of 3DPS cocreation. The research findings benefit enterprises engaged in the 3D printing service and will also facilitate promotion of co-creation which is an emerging strategy in 3D printing. In addition, this study focuses on an interesting topic for DFAM research.

\section{Theoretical basis}

A pair of theoretical models was applied to build a systematic framework in this research. The first one is the Den Hertog's model of service innovation (hereafter referred to as the Den Hertog's model). As shown in Fig.1, this model presents four dimensions including new service concept, new client interface, new service delivery system, and technological options (Hertog, 2000). This framework maps service innovation and discusses the practical development of new services, such as the 3DPS co-creation, namely the topic of this paper.

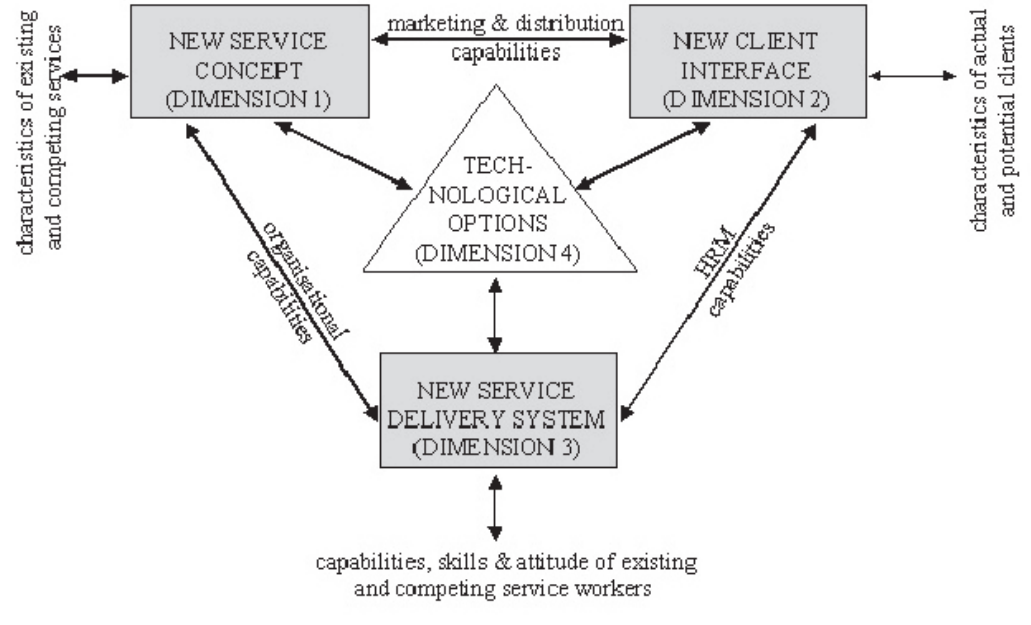

Fig. 1 Den Hertog's Model of Service Innovation (2000).

Another model, as shown in Fig.2, refers to the building blocks of interactions for value co-creation: dialogue, access, risk-benefits, and transparency (hereafter referred to as the DART model). It presents the components in basis construction, which are necessary for the interactions between a consumer and a service provider (Prahalad \& Ramaswamy, 2004). This model describes how to build a system for cocreation of values. 


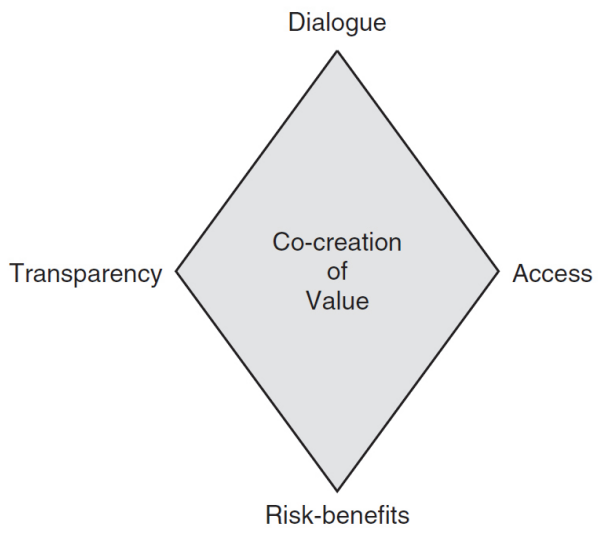

Fig. 2 Building Blocks of Interactions for Value Co-creation. Prahalad \& Ramaswamy, (2004)

\section{Research design}

First of all, this research distinguished ambiguous type and definite type of 3DPS co-creation according to the service goal. The former, like CUBETEAM design app (https://cubeteam.io/) displayed in Fig.3, provides users with a completely open innovation environment in which any possible work might be created and then treated by $3 \mathrm{D}$ printing. The latter refers to flexible formats employed by users to reach a specific design goal, such as jewelry, decor, and characters. Fig.4 shows RADIOLARIA (http://n-e-r-v-ou-s.com/radiolaria/), an online design application for designing and 3D printing customized earring. Its pieces were based on "physical simulation of springs arranged in a cellular mesh" (Derringer, 2010). With regard to the Nervous System, a US-based generative design studio launches Radiolaria and a broad range of 3D printing apps. Such definite-type samples were taken as the current research objects, because it presents a systematic scope of services.
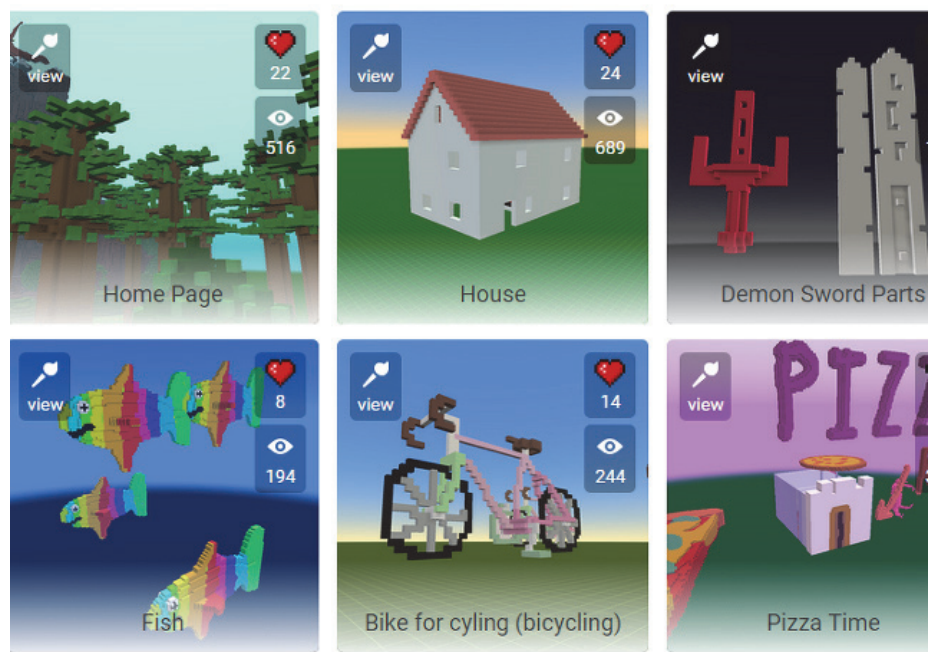

Fig. 3 CUBETEAM Design Application 


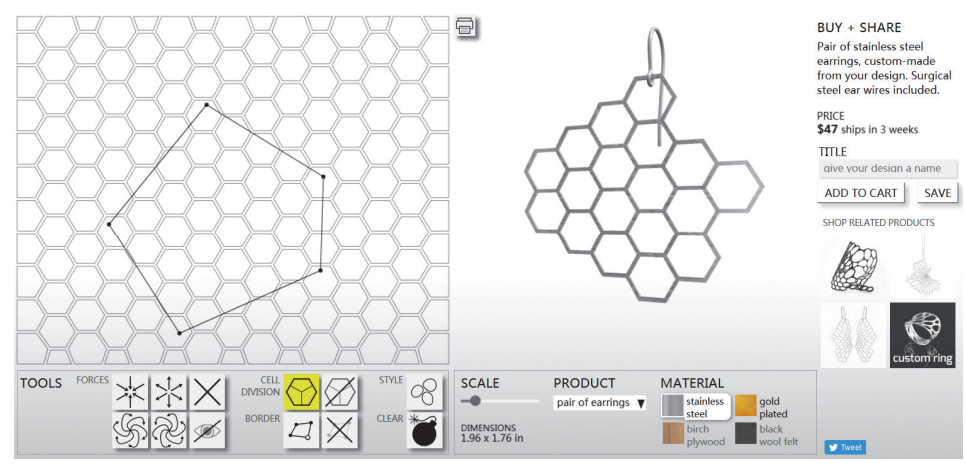

Fig. 4 RADIOLARIA Design Application

The research aims to solve one problem, namely, what the essential components constructing the 3DPS co-creation are. In order to explore the solutions, the evidence needed to be collected through observation and description of the definite-type samples. As a type of emerging technology application, the number of targeted 3DPS co-creation is still greatly limited. Therefore, an inductive approach based on qualitative case study was adopted (Eisenhardt, 1989; Yin, 2003). This study aimed to define a systematic design method for developing the co-creation of 3DPS, so multiple-case study became the most suitable manner for this kind of research (Yin, 2003).

Basically, current study was divided into three parts: preparation for data collection, collection of the evidences, and analysis of the evidences. The first part consists of case selection and formulation of the evidence-collection procedures; based on two theoretical models, an investigation framework is formulated and applied in this part. In the second part, the collected evidences are presented in a systematic way. In the third part, through analysis of the evidences, solutions to the research questions will be proposed.

\section{Preparation for data collection}

\subsection{Case selection}

With regard to the case study samples, authors selected four applications of 3DPS co-creation according to these standards. Firstly, as mentioned before in Chapter 3, the goal of samples must be clear and definite. Secondly, selected cases should respectively stand for a specific category. In particular industries, this criterion facilitates collection of adequate evidence from a responding co-creation process in 3DPS. As shown in Table 1, samples are classified into four categories including Jewelry \& Fashion, Decor \& Houseware, Characters \& Creatures, and Terrain \& Geography. Thirdly, these cases should be set up by different enterprises. Therefore, a wide range of co-creation features would be involved in the following survey. 
Table 1 Case Study Samples

\begin{tabular}{|c|c|c|c|}
\hline Samples & Categories & Summaries & $\begin{array}{c}\text { Web } \\
\text { addresses }\end{array}$ \\
\hline RADIOLARIA & $\begin{array}{l}\text { Jewelry \& } \\
\text { Fashion }\end{array}$ & $\begin{array}{l}\text { A co-creation service which } \\
\text { provides a customized earring and } \\
\text { carries out 3D printing to it for the } \\
\text { customer }\end{array}$ & $\begin{array}{l}\frac{\mathrm{http}: / / \mathrm{n}-\mathrm{e}-\mathrm{r}-\mathrm{v}-}{\mathrm{o}-\mathrm{u}-} \\
\frac{\text { s.com } / \text { radiolari }}{\mathrm{a} /}\end{array}$ \\
\hline $\begin{array}{l}\text { COOKIE } \\
\text { CASTER }\end{array}$ & $\begin{array}{c}\text { Decor \& } \\
\text { Houseware }\end{array}$ & $\begin{array}{l}\text { A co-creation service which } \\
\text { provides customized cookie cutter } \\
\text { for the customer. The co-created } \\
\text { outcome is ready for } 3 \mathrm{D} \text { printing } \\
\text { through the customer downloading. }\end{array}$ & $\frac{\text { http://www.coo }}{\text { kiecaster.com/ }}$ \\
\hline $\begin{array}{c}\text { PUPWORKSHO } \\
\text { P }\end{array}$ & $\begin{array}{l}\text { Characters } \\
\& \text { Creatures }\end{array}$ & $\begin{array}{l}\text { A co-creation service which } \\
\text { provides a customized toy pup and } \\
\text { carries out 3D printing of it for the } \\
\text { customer }\end{array}$ & $\begin{array}{l}\frac{\text { http://pupwork }}{\text { shop.com/ }} \\
\text { shom }\end{array}$ \\
\hline $\begin{array}{c}\text { BENGLER } \\
\text { TERRAFAB }\end{array}$ & $\begin{array}{l}\text { Terrain \& } \\
\text { Geography }\end{array}$ & $\begin{array}{l}\text { A co-creation service which } \\
\text { provides a customized Norwegian } \\
\text { miniature landscape and carries out } \\
\text { 3D printing of it for the customer. } \\
\text { The co-created outcome also gets } \\
\text { ready for 3D printing through the } \\
\text { customer downloading. }\end{array}$ & $\frac{\underline{\mathrm{http}: / / \text { terrafab.b }}}{\underline{\text { engler.no/ }}}$ \\
\hline
\end{tabular}

\subsection{Formulation of the evidence collection}

In order to collect systematic evidences of each case, this task was performed at two main steps based on the Den Hertog's model including service concept, client interface, service delivery system, technological options, as well as the DART model including dialogue, access, risk-benefits, transparency. As shown in Table 2, a framework, in which the essential components of 3DPS co-creation were investigated and defined, was developed.

Table 2 Case Study Framework

\begin{tabular}{|c|c|c|c|}
\hline Sample & \multicolumn{2}{|c|}{ Detailed items } & Evidences \\
\hline \multirow{8}{*}{$\begin{array}{c}\text { Sample } \\
\text { name }\end{array}$} & \multirow{4}{*}{$\begin{array}{c}\text { Items of } \\
\text { Den } \\
\text { Hertog's } \\
\text { model }\end{array}$} & Service concept & \\
\hline & & Client interface & \\
\hline & & $\begin{array}{c}\text { Service delivery } \\
\text { system }\end{array}$ & \\
\hline & & $\begin{array}{l}\text { Technological } \\
\text { options }\end{array}$ & \\
\hline & \multirow{4}{*}{$\begin{array}{c}\text { Items of } \\
\text { DART } \\
\text { model }\end{array}$} & Dialogue & \\
\hline & & Access & \\
\hline & & Risk-benefits & \\
\hline & & Transparency & \\
\hline
\end{tabular}




\section{Collection of evidences}

According to summarization the survey results based on selected 3DPS co-creation samples, the detailed case evidences are listed in following four tables.

Table 3 Case Evidences of RADIOLARIA

\begin{tabular}{|c|c|c|c|}
\hline Sample & \multicolumn{2}{|c|}{ Detailed items } & \multirow{2}{*}{$\begin{array}{l}\text { Evidences } \\
\text { - A co-creation service which provides a customized earring } \\
\text { for the customer }\end{array}$} \\
\hline \multirow{8}{*}{ RADIOLARIA } & \multirow{4}{*}{$\begin{array}{l}\text { Items of } \\
\text { Den } \\
\text { Hertog's } \\
\text { model }\end{array}$} & $\begin{array}{l}\text { Service } \\
\text { concept }\end{array}$ & \\
\hline & & $\begin{array}{l}\text { Client } \\
\text { interface }\end{array}$ & $\begin{array}{l}\text { - The interface for introducing RADIOLARIA service } \\
\text { concept. } \\
\text { - The interface for co-creating the earring features including } \\
\text { form, scale, and material } \\
\text { - The interface for purchasing the co-created earring. }\end{array}$ \\
\hline & & $\begin{array}{l}\text { Service } \\
\text { delivery } \\
\text { system }\end{array}$ & $\begin{array}{l}\text { - Displaying its purchase path, including knowing price, } \\
\text { adding to cart, and paying, the co-created earring is ready for } \\
\text { 3D printing and will be shipped to the customer. }\end{array}$ \\
\hline & & $\begin{array}{l}\text { Technological } \\
\text { options }\end{array}$ & $\begin{array}{l}\text { - WebGL technology for rendering interactive 3D graphics } \\
\text { of co-created earring within web browser } \\
\text { - Multiple 3D printing technologies for producing the co- } \\
\text { created earring } \\
\text { - Generative design program for building flexible and } \\
\text { complex 3D model of the co-created earring }\end{array}$ \\
\hline & \multirow{4}{*}{$\begin{array}{l}\text { Items of } \\
\text { DART } \\
\text { model }\end{array}$} & Dialogue & $\begin{array}{l}\text { - The dialogue between customer and introduction of } \\
\text { RADIOLARIA } \\
\text { - The dialogue between customer and co-creation of the } \\
\text { earring } \\
\text { - The dialogue between customer and purchase of the co- } \\
\text { created earring }\end{array}$ \\
\hline & & Access & $\begin{array}{l}\text { - The accesses of introducing RADIOLARIA } \\
\text { - The accesses of co-creating earring } \\
\text { - The accesses of purchasing the co-created earring }\end{array}$ \\
\hline & & Risk-benefits & $\begin{array}{l}\text { - RADIOLARIA allows the consumer to make a purchase } \\
\text { decision according to the personal understanding of risk- } \\
\text { benefits. }\end{array}$ \\
\hline & & Transparency & $\begin{array}{l}\text { - Each service process is transparent except for 3D printing } \\
\text { of the co-created earring by the RADIOLARIA provider. }\end{array}$ \\
\hline
\end{tabular}

Table 4 Case Evidences of COOKIE CASTER 


\begin{tabular}{|c|c|c|c|}
\hline Sample & \multicolumn{2}{|c|}{ Detailed items } & \multirow{2}{*}{$\begin{array}{l}\text { Evidences } \\
\text { - A co-creation service which provides customized cookie } \\
\text { cutter for the customer }\end{array}$} \\
\hline \multirow{8}{*}{$\begin{array}{l}\text { COOKIE } \\
\text { CASTER }\end{array}$} & \multirow{4}{*}{$\begin{array}{l}\text { Items of } \\
\text { Den } \\
\text { Hertog's } \\
\text { model }\end{array}$} & $\begin{array}{l}\text { Service } \\
\text { concept }\end{array}$ & \\
\hline & & $\begin{array}{c}\text { Client } \\
\text { interface }\end{array}$ & $\begin{array}{l}\text { - The interface for introducing COOKIE CASTER service } \\
\text { concept } \\
\text { - The interface for co-creating the cookie cutter features } \\
\text { including shape, height, and thickness } \\
\text { - The interface for downloading the co-created cookie cutter }\end{array}$ \\
\hline & & $\begin{array}{l}\text { Service } \\
\text { delivery } \\
\text { system }\end{array}$ & $\begin{array}{l}\text { - Displaying a button of 3D file download, the co-created } \\
\text { cookie cutter is ready for 3D printing through the customer } \\
\text { self-service. }\end{array}$ \\
\hline & & $\begin{array}{l}\text { Technological } \\
\text { options }\end{array}$ & $\begin{array}{l}\text { - WebGL technology for rendering interactive 3D graphics of } \\
\text { co-created cookie cutter within web browser }\end{array}$ \\
\hline & \multirow{4}{*}{$\begin{array}{l}\text { Items of } \\
\text { DART } \\
\text { model }\end{array}$} & Dialogue & $\begin{array}{l}\text { - The dialogue between customer and introduction of } \\
\text { COOKIE CASTER. } \\
\text { - The dialogue between customer and co-creation of cookie } \\
\text { cutter } \\
\text { - The dialogue between customer and downloading of the } \\
\text { cookie cutter }\end{array}$ \\
\hline & & Access & $\begin{array}{l}\text { - The accesses of introducing COOKIE CASTER } \\
\text { - The accesses of co-creating cookie cutter } \\
\text { - The accesses of downloading the co-created cookie cutter }\end{array}$ \\
\hline & & Risk-benefits & $\begin{array}{l}\text { - COOKIE CASTER allows the consumer to freely download } \\
\text { the co-created cookie cutter, which brings benefits without } \\
\text { risk. }\end{array}$ \\
\hline & & Transparency & - Each service process is transparent. \\
\hline
\end{tabular}


Table 5 Case Evidences of PUPWORKSHOP

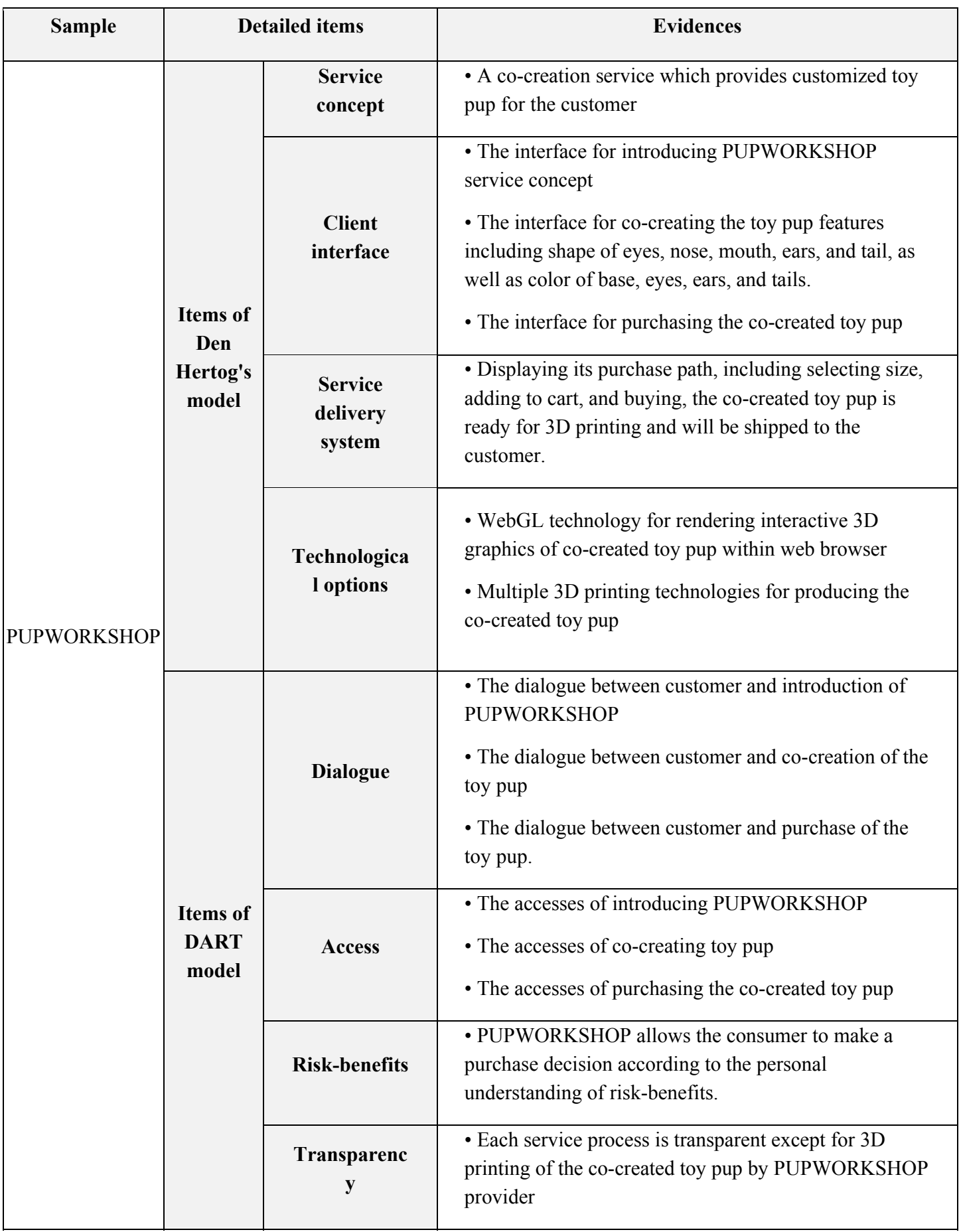


Table 6 Case Evidences of BENGLER TERRAFAB

\begin{tabular}{|c|c|c|c|}
\hline Sample & \multicolumn{2}{|c|}{ Detailed items } & Evidences \\
\hline \multirow{8}{*}{$\begin{array}{l}\text { BENGLER } \\
\text { TERRAFAB }\end{array}$} & \multirow{4}{*}{$\begin{array}{l}\text { Items of } \\
\text { Den } \\
\text { Hertog's } \\
\text { model }\end{array}$} & $\begin{array}{l}\text { Service } \\
\text { concept }\end{array}$ & $\begin{array}{l}\text { - A co-creation service which provides customized } \\
\text { miniature landscape for the customer }\end{array}$ \\
\hline & & $\begin{array}{l}\text { Client } \\
\text { interface }\end{array}$ & $\begin{array}{l}\text { - The interface for introducing BENGLER TERRAFAB } \\
\text { service concept } \\
\text { - The interface for generating the miniature landscape } \\
\text { through the customer co-creation } \\
\text { - The interface for purchasing the co-created miniature } \\
\text { landscape }\end{array}$ \\
\hline & & $\begin{array}{l}\text { Service } \\
\text { delivery } \\
\text { system }\end{array}$ & $\begin{array}{l}\text { - Displaying its purchase path, including selecting size, } \\
\text { adding to cart, and paying, the co-created miniature } \\
\text { landscape is ready for full-color 3D printing and will be } \\
\text { shipped to the customer. } \\
\text { - Displaying a button of download 3D-mesh, the co-created } \\
\text { miniature landscape also is ready for 3D printing through } \\
\text { the customer self-service. }\end{array}$ \\
\hline & & $\begin{array}{l}\text { Technological } \\
\text { options }\end{array}$ & $\begin{array}{l}\text { - WebGL technology for rendering interactive 3D graphics } \\
\text { of co-created earring within web browser } \\
\text { - Multiple 3D printing technologies for producing the co- } \\
\text { created earring } \\
\text { - MapServer technology for publishing interactive mapping } \\
\text { applications to the web }\end{array}$ \\
\hline & \multirow{4}{*}{$\begin{array}{l}\text { Items of } \\
\text { DART } \\
\text { model }\end{array}$} & Dialogue & $\begin{array}{l}\text { - The dialogue between customer and introduction of } \\
\text { BENGLER TERRAFAB } \\
\text { - The dialogue between customer and co-creation of } \\
\text { miniature landscape } \\
\text { - The dialogue between customer and purchase as well as } \\
\text { downloading of the miniature landscape }\end{array}$ \\
\hline & & Access & $\begin{array}{l}\text { - The accesses of introducing BENGLER TERRAFAB } \\
\text { - The accesses of co-creating miniature landscape. } \\
\text { - The accesses of purchasing the co-created miniature } \\
\text { landscape or downloading its digital 3D model }\end{array}$ \\
\hline & & Risk-benefits & $\begin{array}{l}\text { - BENGLER TERRAFAB allows the consumer to make a } \\
\text { purchase decision according to the personal understanding } \\
\text { of risk-benefits. }\end{array}$ \\
\hline & & Transparency & $\begin{array}{l}\text { - Each service process is transparent except for 3D printing } \\
\text { of the co-created miniature landscape by BENGLER } \\
\text { TERRAFAB provider. }\end{array}$ \\
\hline
\end{tabular}




\section{Analysis of evidences}

In order to find the essential components of 3DPS co-creation, the above evidences are analyzed in this section.

In this system, first and foremost, three accesses mainly facilitate the structure of this 3D printing-based customized service. These accesses provide a customer with the entrances of knowing service concept, co-creating geometry, and accepting service delivery. Secondly, the interfaces bring corresponding dialogues between accesses and the customer to reach each process goal. In particular, the WebGL-based co-creating interface displays a range of design variables, which can be adjusted by the customer to generate personal creation. Thirdly, the outcome of co-creation refers to the 3D printed artifact or 3D digital model. The service provider produces the co-created geometry through application of the 3D printing technology, and ships it to the customer. Sometimes, the 3D model file is available for downloading of the customer. Last but not least, transparency plays an important role in stabilizing the system of 3DPS co-creation as it helps the customer obtain clear understanding of co-creation, purchase and downloading.

Finally, this research found that the system of 3DPS co-creation is composed by three dialogues consisting of related accesses and interfaces, and the to-be-3D printed outcome.

\section{Conclusion}

In the context of co-creation service, 3D printing technology performs outstandingly in customized artifact production. A considerable number of 3DPS co-creation applications have been realized in these emerging industries. However, studies about the design method for building the 3DPS co-creation are quite insufficient. In this research, the holistic multiple-case study was carried out to find its essential components. Investigation findings showed that this type of 3D printing-based customized service was composed by three dialogues respectively regarding to service concept, co-created geometry, and service delivery, as well as the service outcomes such as the $3 \mathrm{D}$ printed artifact or its digital file.

In conclusion, the systematic design method for co-creation of 3DPS is presented in the Fig.5. This model has two basic tiers, with three components in the interface tire and three ones in the access tire. In order to design the co-creation of 3DPS, the service provider needs to follow four steps, wherein three dialogues and one outcome group are facilitated. At the first step, the dialogue 1 with the interface of service concept introduction and the access of knowing it is constructed. At the second step, the related dialogue is facilitated based on the interface of co-creation with design variables and the access of co-creating geometry. Here, WebGL and other technologies generate 3D graphics on this definite process. The third step requires the service provider to construct a dialogue for service delivery, in which two components including the interface of purchasing or downloading, and the access of accepting service delivery are occupied. At the fourth step, the customized artifact needs to be treated by 3D printing and then delivered to a customer; or a 3D digital model gets ready for downloading. In addition, the service provider needs to guarantee the transparency as it enables a customer to clearly recognize the possible benefits or risks. 


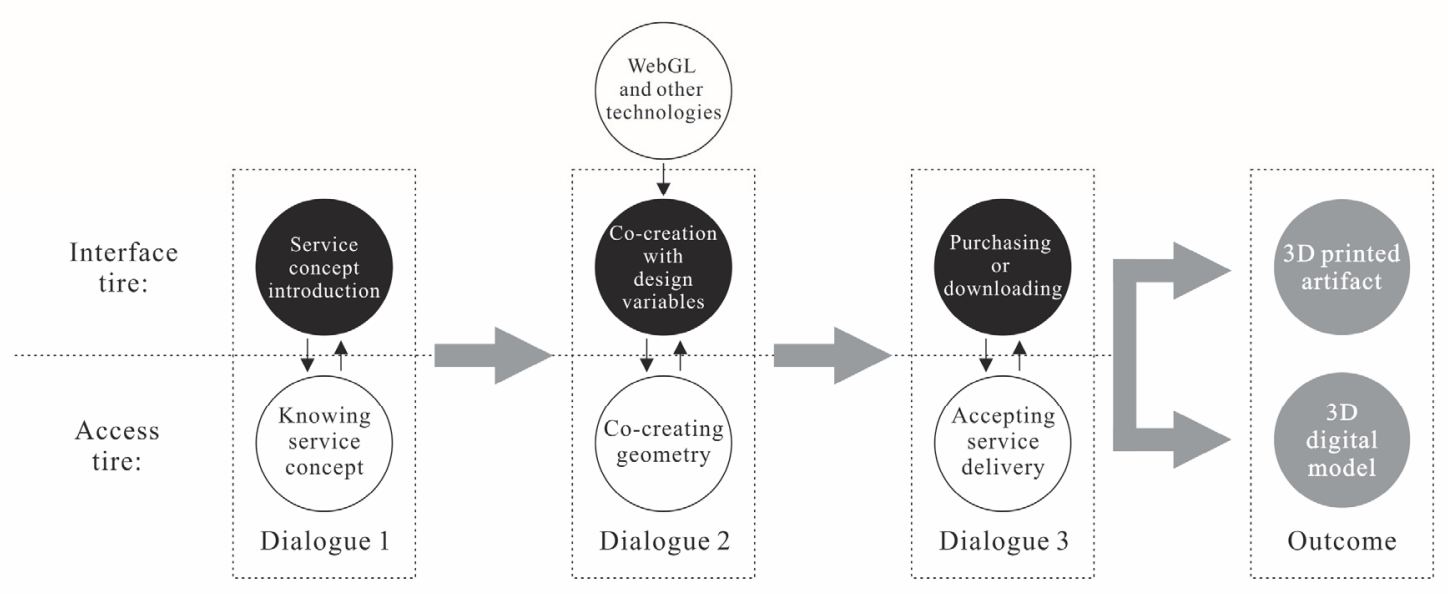

Fig. 2 Model of Systematic Design Method for Co-creation of 3DPS

\section{Limitations}

The first limitation lies in the research scope: this research only focused on the definite-type 3DPS cocreation, but failed to involve other types. The second limitation lies in that this research had not yet involved evaluation of the business efficiency of the 3DPS co-creation. This kind of service innovation requires an investment without the guarantee of success (Dervojeda et al., 2014, p.11), so the service supplier shall think carefully about the possible risks.

\section{References}

DERRINGE, J. (2010) Cell Cycle by Nervous System. $<$ http://design-milk.com/deconstruction-cell-cycle-by-nervoussystem> [Retrieved October 11, 2010]

DERVOJEDA, K., VERZIJL, D., NAGTEGAA, F., LEONGTON, M., ROUWMAAT, E., MONFARD, E., \& FRIDERES, L. (2014). Design for innovation: co-creation design as a new way of value creation. European Union.

EISENHARDT, K. M. (1989). Building theories from case study research. Academy of management review, 14(4), $532-550$

GIBSON, I., ROSEN, D. W., \& STUCKER, B. (2010). Additive manufacturing technologies. New York: Springer.

HERTOG, P. D. (2000). Knowledge-intensive business services as co-producers of innovation. International Journal of Innovation Management, 4(04), 491-528.

NAMBISAN, S. (2002). Designing virtual customer environments for new product development: Toward a theory. Academy of Management Review, 27(3), 392-413.

PILLER, F. T., \& TSENG, M. M. (Eds.). (2010). Handbook of research in mass customization and personalization (Vol. 1, p. 188). Singapore: World scientific.

PRAHALAD, C. K., \& RAMASWAMY, V. (2004). Co-creation experiences: The next practice in value creation. Journal of interactive marketing, 18(3), 5-14.

RAYNA, T., STRIUKOVA, L., \& DARLINGTON, J. (2015). Co-creation and user innovation: The role of online 3D printing platforms. Journal of Engineering and Technology Management, 37, 90-102.

SANDERS, E. B. N., \& STAPPERS, P. J. (2008). Co-creation and the new landscapes of design. Co-design, 4(1), 518.4 .

YIN, R. K. (2013). Case study research: Design and methods. Sage publications. 